\title{
Anti-monopoly Law of China: A Case Study of Coca Cola's Proposed Merger with Huiyuan
}

\author{
Nishan-E-Hyder Soomro , Asif Khan, Ahmed Arafa \\ School of Law and Economic, Zhengzhou University, Zhengzhou, China \\ Email address: \\ nishanehydersoomro@gs.zzu.edu.cn (Nishan-E-Hyder S.), drasifphdlaw@yahoo.com (Asif K.), ahmedarafa667@yahoo.com (Ahmed A.) \\ ${ }^{*}$ Corresponding author
}

To cite this article:

Nishan-E-Hyder Soomro, Asif Khan, Ahmed Arafa. Anti-monopoly Law of China: A Case Study of Coca Cola's Proposed Merger with Huiyuan. International Journal of Business and Economics Research. Vol. 10, No. 1, 2021, pp. 34-39. doi: 10.11648/j.ijber.20211001.15

Received: December 9, 2020; Accepted: January 5, 2021; Published: January 18, 2021

\begin{abstract}
An attempt is made by this study in order to determine whether AML is for protectionism or a leap forward. For this reason, the first part of this article sheds light on AMLs background along with aims and objectives of it while providing a precise glimpse into proposed merger under the AML. For this reason, the researcher took Coca Cola's case in China. In addition to this, some concerns raised by scholars over the decision of China with regard to Coca Cola's merger with Huiyuan are also addressed. The third part of this paper lays out a legal framework in order to create as well as implement AML, with special focus on the process of merger review. It is argued by the researcher that Coca Cola's proposed merger was blocked by China under AML, which also drew world's attention along with criticism. The reason is China flexed its antitrust practice muscles at the expense of this since a Coca Cola's merger was blocked; while there is no doubt that it always attracts international business community. For decades China has been seen as the land of opportunity and growth for foreign investors and only time will determine whether this decision signals a change in that policy. The role of protectionism is explained by part three while investigating concerns with reference to public interests under AML. In this section, underlying rationale to block merger of Coca Cola with Huiyuan is analyzed by proposing that how can improvement be made by China in the merger review process. China made us believe that the decision to block such merger was for lessening and protecting competition, however, clear guidelines are greatly required by enforcement agencies in order to follow as well as increase transparency in the processes of decision making, it would ultimately help china to make better plans for enterprises in the future while showing China as a greatly attractive and fertile ground in order to grow and expand. The paper is concluded in part four along suggesting the adoption of clear merger guidelines which would diminish all the concerns raised by legal scholars; such guidelines would help foreign firms in terms of merger with domestic enterprise in China in the future. Qualitative research methodology has been applied to the following article.
\end{abstract}

Keywords: China, AML, Protectionism, Competition, Merger

\section{Introduction}

The Anti-Monopoly Law (AML) was given to the people of China on August 30, 2007 in China, whereas its implementation was made possible in August 1, 2008. It can be regarded as China's monopoly law in a broad sense; it doesn't only include AML but all the legal as well as administrative documents which existed before AML along with administrative or regulatory enforcement [1]. In addition to this, judicial and private procedures will also be included. The aim of AML was to express the objective of "preventing and restraining monopolistic conducts, protecting fair competition in the market, enhancing economic efficiency, safeguarding the interests of consumers and social public interest, and promoting the healthy development of the socialist market economy." [2]. Till today, there are many questions which have been un addressed, and need to be solved. Such questions include how this law would serve china to achieve its intended objectives and what approach would be adopted by china in order to address antitrust issues. Whether or not this would be used by China as a tool for providing a way forward to protectionist agenda, is the matter of great significant [3].

It is important to note that in 2009 China was among those 
countries that experienced economic growth in terms of GPA. Many concerns have been raised while ignoring that AML's stated objectives focus on protecting the social and consumer public interests by Chinese law enforcement agencies. However, it has been argued by many legal scholars that China's approach to anti-monopoly law is same as European Union and USA, but China is facing many challenges in the global market being a new player by balancing all the concerns which have been raised with regard to financial crisis, unemployment and Chinese domestic industries [2]. Chinese AML's would definitely be influenced by present global financial situation. It cannot be ignored that china among successful markets at global level, therefore, it attracts global cooperation. Moreover, it would have a greater impact on the stability of Chinese domestic enterprises while continuing foreign investment. The first part of this article sheds light on AMLs background along with aims and objectives of it while providing a precise glimpse into proposed merger under the AML. For this reason, the researcher took Coca Cola's case in China. In addition to this, some concerns raised by scholars over the decision of China with regard to Coca Cola's merger with Huiyuan are also addressed. The third part of this paper lays out a legal framework in order to create as well as implement AML, with special focus on the process of merger review. The role of protectionism is explained by part III while investigating concerns with reference to public interests under AML. In this section, underlying rationale to block merger of Coca Cola with Huiyuan is analyzed by proposing that how can improvement be made by China in the merger review process. The paper is concluded in part 4 along suggesting the adoption of clear merger guidelines which would diminish all the concerns raised by legal scholars; such guidelines would help foreign firms in terms of merger with domestic enterprise in China in the future.

\subsection{Background}

AML was formally placed on the legislative agenda in May 1994, and a group was formed by the government to draft an antimonopoly law. From the SAIC and the SETC (State Economic and Trade Commission), the group was drawn. In November 1999, the first complete law's draft appeared. Most of the features of AML were included in this draft whose effect occurred in August, 2008 [4]. During the legislative procedures, many issues were debated heavily such as cartels' treatment and takeover by foreign enterprises, administrative monopoly's issue and policy towards SOEs. Some of the general features of AML must be noted before considering its details. There is similarity between AML and standard best-practice competition laws: on anticompetitive agreements, its general prohibitions, dominance's abuse, and anti-competitive mergers are in language that resembles with most OECD countries. Rather than North American, law's flavor is broadly European and especially Germanic [4]. The scope of AML covers the complete economy so it is comprehensive, although some provisions for exemptions and exclusions also exist which are similar to those in most
OECD countries, though more extensive in context of tone, as discussed later. Sanctions, administrative processes and legal procedures are also established by the AML. While the Chinese have generally sought to adopt best practice of world, it is also evident that the AML has "Chinese characteristics"; Chinese authorities have proclaimed this point and it is discussed below.

Prohibition on the administrative powers to restrict or eliminate competition is AML's unusual feature. The reason of this feature being unusual is that by businesses, most competition statutes are restricted to anti-competitive behavior. Similar to the EU and US competition laws, the expression of AML is in broad language. For Chinese laws to be uttered in general manner is customary. At some point, ambiguous language is incorporated deliberately by AML so that space for discretion is left and also for future development and unresolved policy questions are accommodated. It is intended that rulings, regulations and guidelines define AML. To comprehend it, guidelines need to be looked which accompany it and specific decisions as well. As discussed in Sect, a few guidelines have already been printed [5].

\subsection{Literature Review}

Competition law scholars have paid great attention to the impact of anti-monopoly or competition law on various countries. Moreover, comparison of various countries has also been made. Therefore, many researchers have also conducted research on China's Anti-monopoly law, however, this study is new since no researcher has ever conducted research while taking into account COCA COLA'S proposed merger with Huiyuan. According to Stanley [13] and Nielson [14], after so many struggles, Anti-monopoly law was enacted in China in 2007, that can be regarded as China's most comprehensive law in the history which deals with market competition. The authors called this law the products of Chinese agencies, foreign commentators, academicians, practitioners, officials as well as practitioners' efforts. Since the researchers called the law a big step in order to establish a commercial law system that would be consistent enough with international systems, traditions as well as norms. However, many concerns were raised by researchers in this regard. For instance, Daudpota [16] argued that there are some ambiguities regarding this law, because it is important to explore that whether or not this law would protect consumer welfare and competition in China, or would it only be utilized to secure indigenous companies in Chinese market. Huang [17] also highlighted the issue regarding IP rights while contending that no guidance is provided by the AML with reference to the abuses of IP rights. However, this provision's earlier drafts gave great, however, insufficient, assurance that such rights' enforcement is according to the laws, which cannot be considered Anti-monopoly law's violation. According to Wang [18], this provision along with Article 17 render a refusal in terms of dealing the abuse of dominance, which has ultimately led to greater concerns of the researchers about AML as a remedy to stop unhealthy 
competition. According to Deborah [19], "a refusal to license, without more, is not typically regarded as a violation of competition laws of most major jurisdictions. The agencies that will likely be comprised within the Anti-Monopoly Enforcement Authority reportedly are, or will soon be, at work on implementing regulations." It has been argued that if great clarity is provided by regulation for enabling competitors to analyze contemplated and current conduct against rules, then there can be possibility of compliance with the AML (Stephen et al., 2011) [26]. However, Naween A. [21] are of the opinion that

"Many of the provisions that have engendered the greatest concerns by commentators could be improved, and those concerns reduced if not eliminated, through such regulations. Concerns that the law may be used to compel dominant hightech firms to grant licenses to competitors, for example, should be addressed through regulations"

Despite of all the shortcomings of this law, the researchers have seen this law enactment as an important step in China, since it would lead to Chinese economy's liberalization. Moreover, it would play an important role in establishing law and order in China. However, there is need to flesh out the law's procedural as well as substantive provisions in order to make it applicable more effectively [22-24].

\subsection{Research Methodology}

The study is descriptive, exploratory and analytical is nature. Therefore, the researcher adopted qualitative approach as a way to conduct this research in an effective manner. In order to conduct this research, both primary and secondary sources were used. Secondary sources included research articles, newspaper articles, books and thesis.

\section{Objectives and General Principles}

General principles and objectives are set out by chapter one of the AML. Article 1 about the aim of law and $4^{\text {th }}$ Article about the basis of founding and application of the competition rules are of particular importance to the comprehension of purposes of the law.

Article 1 states that: This law is enacted for the aim of refraining and preventing monopolistic behavior, protection of fair competition in the market, protecting the interests of social and consumers public interest, enhancement of economic efficiency and promotion of the healthy growth and progress of the socialist market economy [7].

Article 4 states that: Competition rules are implemented and constituted by the State which accord with the socialist market economy, prefers macroeconomic control and regulation and promotes an open, unified, orderly and competitive market system. All these things are regulated and controlled [7].

During the process of drafting, there was fine tuning of the wording and significant repositioning, which echoed disagreements and tensions about the aims of the law. Previous drafts of the law strongly emphasized purposes such as healthy growth and promotion of the socialist market economy; but this was included only as the last of objectives in the final version, though it is evident that it remains of significant importance. Moreover, not like the previous drafts, the final version of draft includes reference to the efficiency's improvement, thereby to that extent bringing the Law in line with competition laws which are economic-based and approaches around the world [2].

\section{Merger Review Process Under the AML: Coca Cola Case}

As it is already known that AML was implemented on 3 Sept, 2008, Coca Cola announced many plans with regard to acquiring Huiyuan Company, this project was of $\$ 2.3$ billion. They made this announcement before the decline of Lehman Brothers Holdings, Inc., it can be regarded as the first event which led to global economic crisis. Huiyuan is considered to be the largest juice company in China which controls Fruit juice market's $42 \%$ in the country (Fatima, 2012). After the proposed merger's announcement, many concerns were raised by the Chinese public expressed over this foreign brand which had monopoly in China's domestic market by getting Huiyuan [9]. An online poll suggests that $80 \%$ of Chinese public went against this merger despite the fact that Coca Cola is very successful brand in China and holds beverage market's $50 \%$ in the country. A special place is held by Huiyuan among Chinese people as they call it a great success story being a domestic brand, which competes its international rivals successfully. Coca Cola's absence in China's domestic market can also not be ignored, because it has greatly helped China in terms of countering economic slowdown [9]. It contributed $15 \%$ in 2009 and $19 \%$ in 2008 in terms of GDP growth. Coca Cola also advertised aggressively for Summer Olympics held in Beijing. However, Chinese government took a decision and didn't allow Coca Cola for proposed merger with Huiyuan in order to enter fruit juice market. Chinese government did this while using AML. A theory of competitive harm was posited by the Ministry of Commerce (MOFCOM) it was based upon leveraging theory, it was said that the dominance of Coca Cola in the market would greatly play its role in restricting or eliminating competition while harming consumers (Ministry of Commerce, 2010). In addition to this, it was feared by MOFCOM that a great market power will be held by Coca Cola after acquisition in fruit juice market because it would control both markets beverage and fruit juice respectively through Huiyuan. Many concerns were raised by MOFCOM that SMEs would greatly hurt by dominance of Coca Cola, which would also be de-motivating for SMEs. The main aim of Chinese government was to protect SMEs which stemmed from this fact that many domestic industries were evenly distributed in China, and local self-sufficiency was greatly favored by centrally-planned economy (MOC, 2010). While on the other hand, Huiyuan is regarded to be the only fruit juice company which is domestic and competing international rivals for decades. It led many academicians 
and scholars to believe that the main aim of MOFOCOM was blocking the proposed merger in order to protect domestic economy of China.

\subsection{Shift from Closed Market to AML in Thirty Years}

Many serious reforms were initiated by the Chinese government in 1994, this was the time when anti-monopoly law was started drafting by State Economic and Trade Commission. However, AML took 30 years to be drafted and this law can be regarded as the longest drafting law in the history of China (MOC, 2010). Amid this drafting process, many rules and regulations were promulgated by China that were related to competition such as "Acts of Price Monopoly" in the year of 2003. Merger review process was also the part of this legislation. Many provisions were made and they laid out guidelines in Chinese domestic enterprise for foreign investors whether or not this acquisition would lead to domination. In 2008, after AML's implementation these provisions were updated by MOFCOM since it added an article which stated that declaration requirements given by AML would be followed by foreign investors, it would unify previous guidelines with reference to AML (AML, 2008). The AML's drafting was conducted while making it completely transparent as compared to other legislation which was ever made in China. Chinese officials got engaged with international community in this regard which as regarded to be greater global victory. Many of the provisions related to foreign investors that were once part of previous law were eliminated (Ministry of Commerce, 2010).

\section{2. $A M L$ in Action}

After 8 months of AML's implementation, there was seen a slow acquisition as well as merger due to global financial crisis. However, there were small AML-related decisions. As a result, uncertainty is much there with regard to what aims and objectives are being pursued by the Chinese government. There is a responsibility of "the Antimonopoly Bureau of MOFCOM" in order to manage mergers' review under AML. Conducting such reviews by AML as an administrative body helps a lot in this regard, since an attempt has been made by Antimonopoly Bureau in terms of creating a unified approach which would help merging review under AML [10]. In addition to this, MOFCOM is also considered to be highly responsible in order to issue special notifications along with guidelines when review is required by potential concentration under AML to anti-competitive impact. Such guidelines have played an immensely significant role in terms of enhancing new merger review scheme's reliability that how MOFCOM conduct merger review (MOFCOM, 2009). In the AML, significant flexibility is provided AML to MOFCOM in the processes of decision making. while providing virtually no notice to would-be merging parties of how a transaction might be analyzed by MOFCOM. There has been lack of transparency merger review's feature in all the analyses which are conducted by MOFCOM. There is no public record of 40 deals that was done under it for analysis. They approved all decisions conditionally while published only one. However, merger of two non-Chinese co-operations was involved in this. An acquisition was blocked by MOFCOM only in the case of Coca-Cola merger [11]. Unlike the others publicly announced decisions, the decision of MOFCOM to Coca Cola merger was publicly announced on March 2009, in a very short notice. This decision was rationalized by MOFCOM in terms of blocking the acquisition while stating that brand dominance would be leveraged by Coca-Cola in the market of soft drink and fruit juice that will also help in eliminating and restricting competition. Additionally, it was announced by MOFCOM that Coca-Cola was given an opportunity for proposing solutions that would help in order to get negative impact reduced in competition, but Coca-Cola did fail in doing so (AML, 2010).

\subsection{Underlying Rationale Behind the Coca-Cola Decision: Protectionist Components}

In order to understand that why decision was made by MOFCOM to block the acquisition of Huiyuan by Coca Cola, and it was protectionist policy which has impacted such decision beyond protecting market from competition. The Chinese government saw harmonious and stable society as a basic goal in order to unify former economy (segmented) while rectifying socio-economic divide between rural and urban population. Such concerns reflected in the attitudes of Chinese government towards competition, and it cannot be called surprising and it can also be believed that competition rules' enforcement of MOFCOM was strongly influenced by it. It isn't equally surprising (MOFCOM, 2010). It has been stated that "...Compound these policy concerns with the pervasive problem of local or regional administrative monopolies over segmented industries throughout China, and MOFCOM's difficulty with focusing solely on competition becomes apparent. Simply put, Chinese officials have an acute awareness of how China trails international counterparts in being able to compete globally in certain industries and while foreign acquisitions bring technical expertise and other efficiencies Chinese industry lacks, Chinese leaders also want to protect key industries against foreign competition" (Wall Street, 2009; US Chamber of Commerce, 2017). As the growth is immense in fruit juice industry, it has made some sense that China wants this industry as a key player in order to protect its domestic market by many global rivals including Coca Cola. Huiyuan cannot be considered a product itself inside the Chinese fruit juice market, where juices were supplied to various regions under 1978 economy (Northwest Wholesale Stationers, 1985). There were seen 300 small and medium enterprises in fruit juice market by 2008 (The Economist, 2009). The block on Coca Cola led to the removal of competition as it was feared that Coca cola would start controlling domestic enterprises, since they believed that Coca cola would control Huiyuan and Huiyuan would lose its status as a successful domestic beverage company. Therefore, it can be argued that the main aim of China was to protect domestic companies instead of high competition due to the merger of Coca Cola 
with Huiyuan. No concerns were voiced by MOFOCM over the blockage of Coca Cola's merger. However, they totally rejected that anything was done to protect the national brand in its analysis [11].

\subsection{Underlying Rationale Behind the Coca-Cola Decision: Competition Components}

Had MOFCOM based its decision in order to block the Coca Cola's merger on anti-competitive concerns as stated by the government of China, or there was another reason as well? The guidelines' absence over how MOFCOM reviewed horizontal merger and it led to the greatest impact market's concentration. There are two factors which can be considered highly critical in order to understand whether or not there will be anti competition effects. It is indicated by the statements which released after Coca Cola's decision that dominance would be used by Coca Cola for promoting Huiyuan's sale in the carbonated market (MOFCOM, 2010). That would play its role hampering competition while driving up prices in juice market. It has been sad that "This "leveraging" theory has found very little support in other global markets, such as the United States. China expressed fear that Coca-Cola would bundle its carbonated beverages with its fruit juice brands (including Huiyuan, post-merger), though ministry officials did not point to any direct evidence to show that Coca-Cola had engaged in such conduct, either with its Minute Maid brand or another product in China." It was argued by MOFCOM that there would have strong market of Coca-Cola in the market of fruit juice beverage since Huiyuan would be controlled by Coca Cola as well as "given its current dominance over the carbonated beverage market and the carryover effect, the concentration will considerably raise barriers for potential competitors to enter the fruit juice beverage market." [12].

It was believed by MOFCOM that medium and small sized enterprise would squeeze due to Coca Cola's acquisition in fruit juice market, which is not good for sustained and sound development of industry in China. Many attempts were made by Coca-Cola in terms of ameliorating such concerns/questions via unpublicized proposals [7]. The Chinese government aimed to address such concerns. However, the proposed merger was rejected by MOFCOM and there was no further information was given to analyze things. But the reason given by MOFOCOM was totally different as they said it fell near international antitrust practices' boundaries. There is no information available with regard to how they determined market's post and pre-merger concentration, and what would have been the impact upon the industry of China after this merger [12]. While keeping in view the growth of fruit juice market, it cannot be surprising to know that players started considering acquisitions as a way to expand the share of market where the relevant market is undersupplied. They said that "as it would be unlikely that any one player could tacitly collude to drive up prices with other market participants absent a highly concentrated market. Could Coca-Cola have been able to maintain supra competitive pricing for its juice brands in light of the fact the fruit juice market in China has hundreds of participants who could potentially expand production and output in order to compete with Coca-Cola and capture unmet demand for fruit juice?" [7]. it is important for MOFOCM to take into consideration that there were so many domestic competitions, and hurdles and barriers to expand or entry were too high than expected (even if no international competitor was involved). However, it cannot be found out that whether or not any analysis has been done over such assumption. There was nothing provided in this decision regarding it. If barrier is not that much high, there would have been no supra competition prices by Coca Cola. According to the researchers, "absent guidelines as to how China might have determined the relevant market, how concentrated the market was pre- and post-merger or the barriers to entry or expansion in the market, Coca-Cola had no expectation of how its acquisition of Huiyuan would be analysed by MOFCOM or what factors would determine the fate of the transaction." [9]. It can be said that such lesson came up with very higher transaction cost with no return investment in case of Coca Cola [10].

\section{Conclusion}

It can be concluded that Coca Cola's proposed merger was blocked by China under AML, which also drew world's attention along with criticism. The reason is China flexed its antitrust practise muscles at the expense of this since a Coca Cola's merger was blocked; while there is no doubt that it always attracts international business community. For decades China has been seen as the land of opportunity and growth for foreign investors and only time will determine whether this decision signals a change in that policy. China made us believe that the decision to block such merger was for lessening and protecting competition, however, clear guidelines are greatly required by enforcement agencies in order to follow as well as increase transparency in the processes of decision making, it would ultimately help china to make better plans for enterprises in the future while showing China as a greatly attractive and fertile ground in order to grow and expand.

\section{References}

[1] Anti-monopoly Law of the People's Republic of China [hereinafter AML], art. 10, available at $\mathrm{http}: / /$ www.china.org.cn/government/laws/200902/10/content 17254169.htm.

[2] Xinzhu Z. \& Vanessa Yanhua Z, (2009), Chinese Merger Control: Patterns and Implications, 6 J. COMPETITION L. \& EcoN. 477, 478. The article reports that MOFCOM had "received" 58 merger notifications and reviewed and closed 46 of them.

[3] Hannah C. L. Ha, et al. (2010) China's Anti-Monopoly Law Merger Control Regime - 10 Key Questions Answered (part 1), Mayer-Brown JSM (Mar. 2, 2010), available at http://www.mayerbrown.com/publicdocs/ClientUpdateChina.pdf. 
[4] Zhenguo W (2008), Perspectives on the Chinese AntiMonopoly Law, 75 ANTITRUST L. J. 73 (2008); Donald C. Clarke, CHINA: CREATING A LEGAL SYSTEM FOR A MARKET ECONOMY (2007), available at http://ssrn.com/abstract=1097587.

[5] Broadcast Music, Inc. v. Columbia Broad. Sys., 441 U.S. 1 (1979); Cal. Dental Ass'n v. Fed. Trade Comm'n, 526 U.S. 756 (1999); Texaco, Inc. v. Dagher, 547 U.S. 1 (2006).

[6] Northwest Wholesale Stationers, Inc. v. Pacific Stationary \& Printing Co., 472 U.S. 284 (1985).

[7] Damien G (2009). The Perils of Antitrust Proliferation - The Process of 'Decentralized Globalization' of Antitrust and the Risk of Over-Regulation of Competitive Behavior, CHI. J. INT'L L. 189, 189 (2009).

[8] Ministry of Commerce of the People's Republic of China, Provisional Rules on the Implementation of Acquisition or Divestiture of Assets or Businesses for Concentrations of Business Operators, Notice No. 41, 2010 (July 5, 2010) [hereinafter Provisional Rules]

[9] Susan B. F, (2009), The Evolution of Chinese Merger Notification Guidelines: A Work in Progress Integrating Global Consensus and Domestic Imperatives, 18 TULANE J. INT'T L. \& COMP. L. 1, 49 (2009).

[10] Mayer-Brown JSM, China's Anti-Monopoly Law Merger Control Regime - 10 Key Questions Answered (Part 1) (Mar. 2 2010), available at http://www.mayerbrown.com/publicdocs/Client-UpdateChina.pdf. Assuming a fairly constant stream of transactions, it is possible that the MOFCOM has reviewed nearly twice that number at the 2-year anniversary of the law.

[11] Coke Offer for Huiyuan Triggers Widespread Worry for Famous Domestic Brand in China, XINHJA (Sept. 4, 2008), available http://english.sina.com/business/2008/0904/184005.html [hereinafter Coke Offer Triggers Worry].

[12] Fei D, Adrian E, Gregory K. Leonard, (2009), A Hard Landing in the Soft Drink Market - MOFCOM's Veto of the Coca-Cola \& Huiyuan Deal, GCP - Global Competition Policy at 3 (Apr. 2009).

[13] Stanley Lubman, 'Bird in a Cage: Chinese Law Reform after Twenty Years' (2000) 20 Northwestern Journal of International Law \& Business 383 at 383-4.
[14] L Nielson, A. (2018). "The Paradox Of Discretionary Competition Law". European Competition And Regulatory Law Review 2 (3): 156-165. doi: 10.21552/core/2018/3/4.

[15] Fatima, S. (2012). "Competition Law In Pakistan: Brief History, Aspirations And Characteristics". Commonwealth Law Bulletin 38 (1): 43-62. doi: 10.1080/03050718.2012.646734.

[16] Daudpota, F. (2013). "Anti-Money Laundering Law Of Pakistan An Overview". SSRN Electronic Journal 12 (3): 2233. doi: $10.2139 / \mathrm{ssrn} .2368483$.

[17] Huang, Y. (2008). Pursuing the second best: The history, momentum, and remaining issues of China's anti-monopoly law. Antitrust Law Journal, 75(1), 117-131.

[18] Wang, X. (2002). The prospect of antimonopoly legislation in China. Washington University Global Studies Law Review, pp. 201-232.

[19] Deborah Healey, 'An Anti-monopoly Law for China: Weapon or Mirage?' (2008) 16 Competition \& Consumer Law Journal 220 at $225-7$.

[20] US Chamber of Commerce, Competing Interests in China's Competition Law Enforcement, 2017 pp. 53-62.

[21] Naween A. Mangi, Comment: Are Flourishing Cartels Reason Enough to Shut Down the Impotent MCA?, DAILY TIMES, available at http://www.dailytimes.com.pk/default.asp? page=story_23-12-2004_pg5.

[22] Xiaoye Wang, 'The New Chinese Anti-monopoly Law: A Survey of a Work in Progress' (2009) 54 Antitrust Bulletin 577 at $584-7$.

[23] Fei Deng and Cunzhen Huang, 'A Five Year Review of Merger Enforcement in China' [2013] (October) The Antitrust Source 1 at 18, available at www.americanbar.org/content/dam/aba/directories/.

[24] Ping Lin and Jingjing Zhao, 'Merger Control Policy under China's Anti-monopoly Law' (2012) 41 Review of Industrial Organization 109 at $123-5$.

[25] Xinzhu Zhang and Vanessa Yanhua Zhang, 'Chinese Merger Control: Patterns and Implications' (2010) 6 Journal of Competition Law and Economics 477 at 492-3.

[26] H. Stephen Harris Jr et al., Antimonopoly Law and Practice in China (New York: Oxford University Press, 2011), pp. 2-3. 